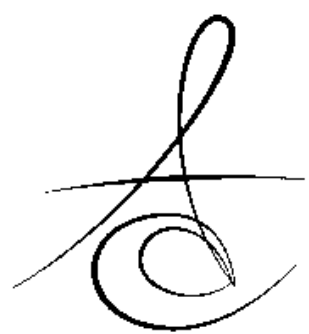

\title{
ÇENE SANTRAL DİŞLERDE ÇİFT TARAFLI TALON TÜBERKÜLÜ: OLGU SUNUMU
}

\section{BILATERAL TALON CUSPS ON PERMANENT MAXILLARY CENTRAL INCISORS: CASE REPORT}

Dr. Gülser KILINÇ*

Doç Dr. Behiye SEZGİN BOLGÜL**

Makale Kodu/Article code: 1720

Makale Gönderilme tarihi: 03.06.2014

Kabul Tarihi: 14.10 .2014

\section{ÖZET}

Talon tüberkülü, üst ve alt çenede süt ve daimi ön dişlerin mine sement bileşim bölgelerinde veya singulumlarında görülen nadir bir diş anomalisidir. Görülme sıklığı toplumsal farklılık olmasına karşın, \%1 den azdır. Tek yada çift taraflı görülebilir. Konuşma bozukluğu, okluzal çatışma, dil ve yumuşak doku yaralanmaları, estetik sorunlar ve çürük gibi klinik problemlere neden olabilir. Bu nedenler için erken tanı bu anomalide önemlidir.

$\mathrm{Bu}$ olgu sunumunda 10 yaşındaki kız hasta, konuşma güçlüğü ve dilde yaralanma şikayeti ile kliniğimize başvurdu. Oral muayenede sağ-sol üst santral dişlerinde talon tüberkülü ve bu bölgede dentin çürüğü tesbit edildi. Talon tüberkülü kademeli olarak kaldırıldı ve çürük dişler kompozit dolgu ile restore edildi.

Bu vaka raporunda, üst çene santral kesici dişin palatinal yüzeyinde görülen talon tüberkülünün aşamalı olarak kaldırılması ve tedavi yaklaşımı sunulmuştur.

Anahtar Kelimeler: Talon tüberkülü, Diş

Anomalisi, Daimi diş

\section{GİRIŞ}

Talon tüberkülü süt ve daimi dentisyonda, üst ve alt çene ön dişlerin mine sement bileşim bölgele- rinde veya singulumlarında görülen diş anomalisidir. ${ }^{1} \mathrm{Bu}$ anormal yapı, normal mine, dentin ve ayrıca değişik boyutlarda pulpa dokusu içerebilir. Bilateral veya ünilateral görülebilir. Talon tüberkülü ilk kez 1842

\section{ABSTRACT}

Talon cusp is a rare dental anomaly that occure in the enamel-cement junction and cingulum area of anterior permanent and primary teeth at maxilla and mandible. Even so social differences, occurrence is less than $\% 1$. It may be unilateral or bilateral. It may be unilateral or bilateral. It may cause some problems like; paraphrasia, occlusal interference, irritation of soft tissues and tongue, , esthetic problems and dental caries. Early diagnosis is important in this anomaly for these reasons. In this case report, a 10 year-old female patient applied to our clinic with the complains of paraphrasia and tongue injuries. In oral examination, talon cusp and dentin caries were determined at left-right upper incisors. Talon cusp was removed fractionally and teeth were restored with composite resin.

In this case report, fractionally removement of the talon cusp that was occured in palatal side of upper incisor and treatment approach were presented.

Key Words: Talon Cusp, Dental Anomalies, Permanent Teeth yılında Carabelli tarafından tarif edilmiştir. ${ }^{2}$ Üst çenede, alt çeneye göre, erkeklerde kızlara göre daha fazla görülmektedir. ${ }^{3,4}$ Görülme prevalansı, toplumdan topluma farklılık göstermektedir. ${ }^{2}$ Etiyolojisi tam olarak bilinmemektedir, ancak genetik ve çevresel faktörlerin rol oynadığı düşünülmektedir. ${ }^{2,4,5}$

Talon tüberkülü en çok maksiller lateral (\%55) dişlerde görülmekte olup, bunu üst santral kesici dişler (\%33), alt çene kesici dişler (\%6) ve üst çene

\footnotetext{
* Dicle Üniversitesi Diş Hekimliği Fakültesi, Çocuk Diş Hekimliği AD.

** Dokuz Eylül Üniversitesi Tıp Fakültesi Çocuk Diş Kliniği,
} 
kanin (\%4) dişler takip eder, daha az oranda premolar ve molar dişlerde görülür. ${ }^{3,6}$

Bu dişler estetik ve fonksiyonel sorunlara neden olabilmektedir. Talon tüberkülü küçük ise hastada herhangi bir sorun oluşturmaz ve tedavi uygulanmaz. ${ }^{4}$ Büyük talon tüberkülü olan hastalarda ise dental problemler ve dilde yaralanmalar görülebilir. Bazı durumlarda dental anomaliyle ilişkili olduğu belirtilmektedir. ${ }^{1-3}$ Hattab ve ark. ${ }^{5} 1996$ yılında talon tüberkülünü formuna ve çıkıntısına göre sınıflandırmıştır(Tablo 1 ).

Tablo 1. Hattab ve ark. ${ }^{5} 1996$ yılında kullandıkları Talon tüberkülü sınıflaması

\begin{tabular}{|l|l|}
\hline Tip 1: Talon & $\begin{array}{l}\text { Süt ve daimi ön dişlerin } \\
\text { arka(palatinal-lingual) yüzeyinde } \\
\text { mine sement bileşiminden } \\
\text { başlayarak dişin yarısına kadar } \\
\text { belirgin olarak genişleyen } \\
\text { morfolojik oluşum }\end{array}$ \\
\hline Tip 2: Semi Talon & $\begin{array}{l}\text { Süt ve daimi ön dişlerin } \\
\text { arka(palatinal-lingual) yüzeyinde } \\
\text { mine sement bileşiminden başlar } \\
\text { ve dişin yarısndan daha azdır, } \\
\text { ancak 1mm den fazladır }\end{array}$ \\
\hline Tip 3: Talon izi & $\begin{array}{l}\text { Bu küçük tüberkül süt ve daimi ön } \\
\text { dişlerin arka(palatinal-lingual) } \\
\text { yüzeyindedişin gingival üçlüsünde } \\
\text { yer alır. T,Y veya V şeklinde } \\
\text { olabilir. }\end{array}$ \\
\hline
\end{tabular}

Talon tüberkülü, Rubinstein-Taybi, Mahr, Sturge-Weber, Orofacial digital II gibi sendromlarla ve diğer odontojenik anomalilerle birlikte görülebildiği belirtilmektedir. ${ }^{7-9}$ Bu durumda hasta ve diş hekimi için erken tanı oldukça önemlidir. ${ }^{4}$

Bu olgu sunumunda talon tüberkülü anlatılmış ve literatür bilgileri ışığında tartışılmıştır.

\section{OLGU SUNUMU}

On yaşındaki kız hasta, Dokuz Eylül Üniversitesi Çocuk diş kliniğine üst ön dişlerinde çürüğe bağlı hassasiyet ve dilde yaralanma şikayeti ile başvurmuştur. Alınan anamnezde hastanın herhangi bir sistemik rahatsızlığı olmadığı ve ailenin tek çocuğu olduğu belirlendi. Hastanın üst santral dişlerinin arka yüzündeki palatinal çıkıntı nedeniyle konuşma ve çiğneme sırasında rahatsız olduğu, ayrıca dilin üst yüzeyi ve uç kısmında zaman zaman yaraların oluştuğu öğrenildi.

Yapılan oral muayenesinde maksiler sağ- sol santral kesici dişinin arka yüzünde, mine sement birleşiminden kesici kenara kadar olan mesafenin yarısına kadar uzanan bir talon tüberkülü görüldü (Resim 1,2). Üst santral dişlerinde geniş retansiyon alanları nedeniyle her iki dişte dentin çürüğü saptandı. Hastadan alınan panoromik radyografide (Resim 3) üst sağ-sol santral dişte mine-sement bileşimine kadar uzanan radyoopak görünüm izlendi. Radyografide talon tüberkülünün pulpa dokusu ile bağlantılı olmadığı görüldü.

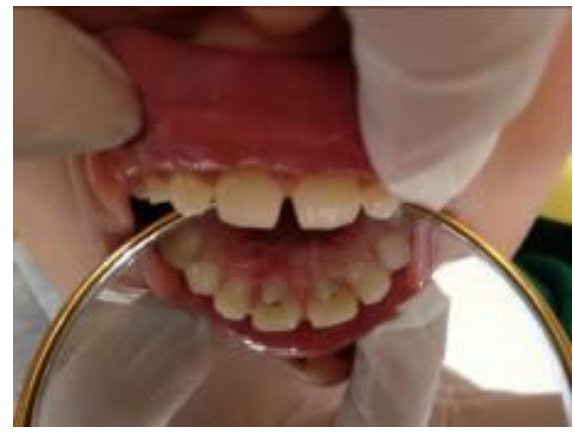

Resim 1. Üst çene her iki santral dişte talon tüberküllerinin ağız içi görünümü

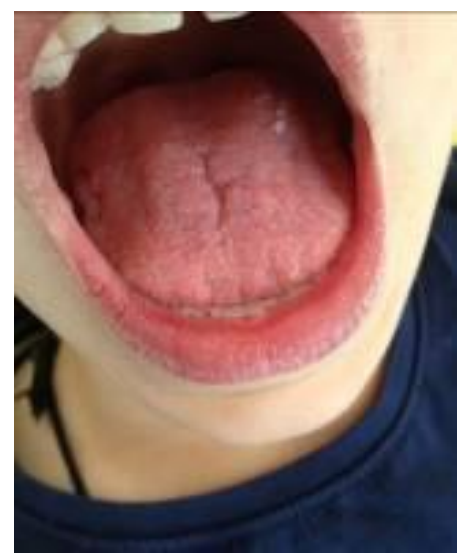

Resim 2. Dil uçunda talon tüberkülünün oluşturduğu travmaya bağlı yarıklar

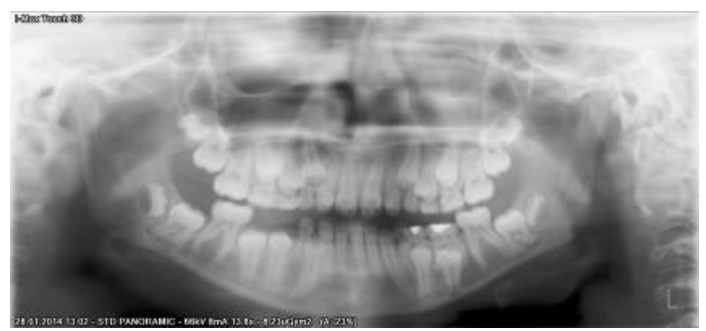

Resim 3. Hastanın panoromik radyografisi ve üst santral dişlerde talon tüberkülünün görünümü

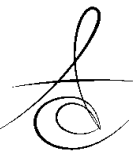


Hastaya, kademeli aşındırma işlemi anlatıldı ve aydınlatılmış onam alındı. İki ay ara ile iki aşamalı olarak talon tüberkülünün yüzeyinden mölleme yapıldı. İlk seansta hastanın var olan dentin çürüğü temizlendi ve talon tüberkülü bir miktar möllendi (Resim 4) ve geçiçi dolgu olarak flor salınımlı cam iyonomer (Compoglass F ivoclar vivadent Liechtenstein) dolgu ile restore edildi. Aşındırma işleminden sonra bu yüzeye florür jeli (Topikal APF gel Sultan USA) uygulandı.

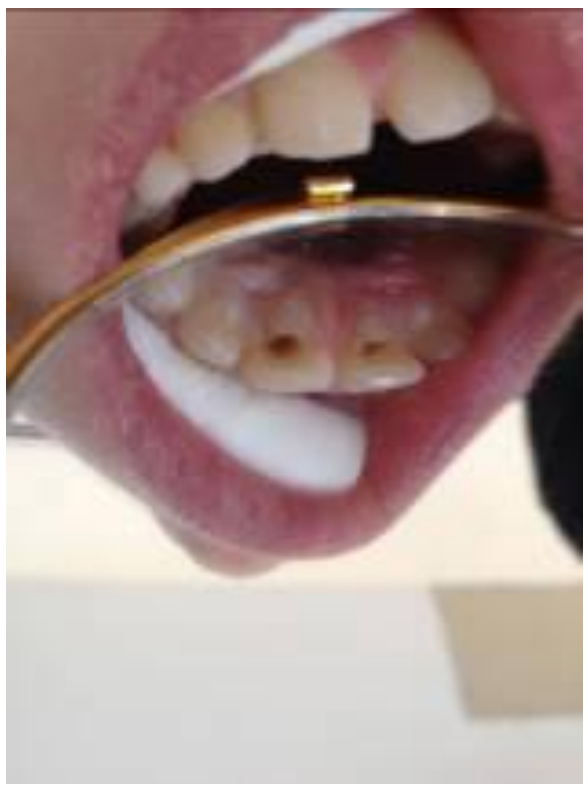

Resim 4. Dişlerdeki dentin çürüğünün temizlenmesi, talon tüberkülünün kademeli olarak kaldırılması

İkinci seansta hastanın şikayetinin bir miktar azalmış olduğu, özellikle dilde talon tüberkülünün oluşturduğu sürtünmeye bağlı yaraların olmadığı gözlendi. Yapılmış olan geçiçi restorasyon çıkarıldı bir miktar daha tüberkülden mölleme yapılarak, kompozit restorasyon (Dentsply TPH3 Spectrum) uygulandı (Resim 5). İki ay sonra yapılan üçüncü kontrolde hasta; dilde, ağız içinde ve dişte hassasiyete yönelik herhangi bir şikayetinin olmadığını belirtti. Hasta halen kontrolümüz altında olup bu dişlerin takibi yapılmaktadır

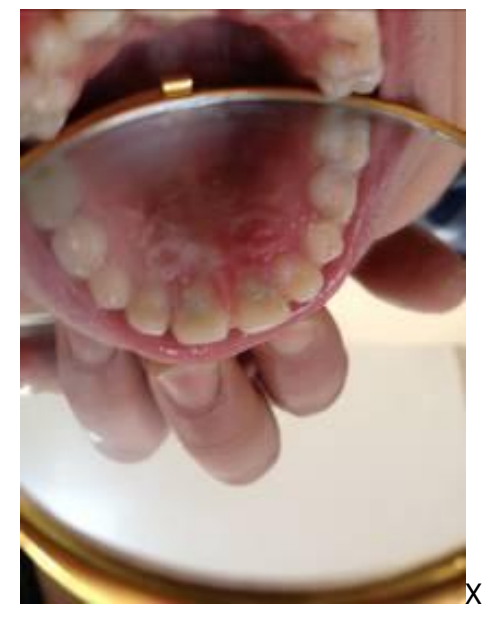

Resim 5. Talon tüberkülllerinin möllenmesi ve kompozit resinle restorasyonu sonrası ağız içi görünümü

\section{TARTIŞMA}

Talon tüberkülünün nedeni tam olarak bilinmemektedir, ancak araştırmacılar dental laminanın hiperaktivitesi sonucu olabileceği gibi, dens invaginatusun başlangıç şekli olabileceğini belirtmektedirler. ${ }^{7,8}$ Talon tüberkülü üst çenede daha fazla oranda görülmektedir. Hattab ve ark. $^{5}$ üst çenede görülme oranını \%92 olduğunu belirtmişlerdir. Genellikle çift taraflı olarak görülmekte olup, talon tüberkülünün tek taraflı görülme prevalansı daha düşüktür. Çift taraflı görülme insidansının \%20 olduğu belirtilmektedir. ${ }^{10}$ Prabhu ve ark. $^{6}$ yaptıkları çalışmada erkeklerde (\%75), kızlardan (\%25) daha fazla görüldüğü belirtilmektedir. Olgudaki kız hastamızın, üst ön santaral dişlerin palatinal yüzeyinde çift taraflı talon tüberkülü görülmüş ve Tip 1 tanısı konulmuştur.

Şıracı ve ark. ${ }^{11}$ yaptıkları çalışmada talon tüberkülünün konuşma sırasında dili rahatsız etmiyor ve çiğneme sırasında okluzyonu etkilemiyorsa herhangi bir müdahale uygulanmaması gerektiğini, ancak talon tüberkülünün mesial ve distalinde tespit edilen gelişimsel oluklara çürük gelişimini engellemek amacıyla fissür örtücü uygulanmasını önemektedir. Segura-Egea ve ark. ${ }^{12}$ talon tüberkülünün çiğneme ve konuşma esnasında dilde irritasyon oluşturduğunu ve karşı dişte okluzal travmaya neden olabildiğini belirtmişlerdir. Hasta kliniğimize konuşma güçlüğü ve dilde yaralanma şikayetiyle başvurmuş olup, hastanın

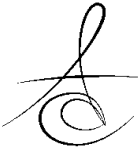


talon tüberkülü olan üst santral dişlerinde mölleme işlemi yapılmış ve var olan dentin çürüğü tedavi edilmiştir. Güngör ve ark. ${ }^{13}$ yaptığı çalışmada talon tüberkülü görülen daimi üst keser dişlerde tüberkül içerisinde pulpa dokusuna rastlamışlar ve talon tüberkülünün möllenmesinde dikkat edilmesi gerektiğini belirtmişlerdir. Hastadan alınan radyografide talon tüberküllü içerisinde pulpa dokusunun olmadığı görülmüştür. Hastanın üst keser dişlerinde bulunan talon tüberkülleri iki ay ara ile iki kez mölleme yapılmıştır. Yapılan çalışmalarda talon tüberkülündeki minenin kademeli olarak möllenmesi ve flor cila uygulanarak hassasiyetin giderilmesinin uygun tedavi yaklaşımı olacağı belirtilmektedir. ${ }^{3,12}$

Sonuç olarak; Talon tüberkülünde uygun tedavi seçeneğinin sağlanabilmesi için klinik ve radyografik tanı önemlidir. Tedavi başarısı tüberkülün büyüklüğüne, uygun tedavi yönteminin seçilmesine ve hasta kooperasyonuna bağ|ıdır.

\section{KAYNAKLAR}

1. Shashikiran ND, Babaji $P$, Reddy VVS. Double facial and a lingual trace talon cusps: A case report. J Indian Soc Pedod Prev Dent 2005;23:89-91.

2. Mavrodisz K, Rózsa N, Budai M, Soós A, Pap I, Tarján I. Prevalence of accessory tooth cusps in a contemporary and ancestral Hungarian population. Eur J Ortho 2007;29:166-9.

3. Şahiner C, Kızlırmak A, Özalp N. Talon tüberkülü dört olgu raporu. A.Ü. Diş Hek Fak. Derg 2009;36:115-20.

4. Arfat B, Çolak $H$, Çelebi AA, Uzgur R, Turkal M, Hamidi MM. The frequency and characteristics of talon cusps in a Turkish population. Eur J Genet Dent 2012;1:39-43.

5. Hattab FN, Yassin OM, Al-Nimri KS. Talon cusp in the permanent dentition associated with other dental anomalies: Review of literature and reports of seven cases. J Dent Child 1996;63:368-76.

6. Prabhu RV, Rao PK, Vena KM, Shetty P, Chatra L, Shenai $P$. Prevalence of talon cups in Indian population. J Clin Exp Dent 2012;4:23-7.

7. Tomazinho FS, Baratto-Filho F, Leonardi DP, Haragushiku GA, de Campos EA. Occurrence of talon cusp on a geminated maxillary central incisor: a case report. J Oral Sci 2009;51:297300.

8. Nadkarni UM, Munshi A, Damle SG. Unusual presentation of talon cusp: two case reports. Int J Paediat Dent 2002;12:332-5.

9. Uyeno DS, Lugo A. Dens evaginatus: a review. J Dent Child 1996;63:328-32.

10. Gündüz K, Çelenk P. Survey of talon cups in permanent dentition of Turkish population. J Contemporary Dent Practice 2008;9:1-8.

11. Şıracı $E$, Tekçiçek $M$, Turgut MD. Talon Tüberkülü Ve Dens İnvajinatus: Ailesel Geçişli Bir Olgu Sunumu. Atatürk Üniv. Diş Hek Fak. Derg. 2005;15:81-7.

12. Segura-Egea JJ, Jiménez-Rubio A, VelascoOrtega E, Ríos-Santos JV. Talon cusp causing occlusal trauma and acute apical periodontitis: report of a case. Dent Traumatol 2003;19:55-9.

13. Güngör HC, Altay N, Kaymaz FF. Pulpal tissue in bilateral talon cusps of primary central incisors. Oral Surg Oral Med Oral Pathol Oral Radiol Endod 2000;89:231-5.

\section{Yazışma Adresi}

Doç Dr. Behiye SEZGIN BOLGÜL

Dicle Üniversitesi Diş Hekimliği Fakültesi, Çocuk Diş Hekimliği AD. Diyarbakır

Tel: 05303492229

e-mail: behiyebolgul@hotmail.com 